\title{
Importance of light conditions for the height growth of underplatings in Norway spruce stands in the Oravské Beskydy Mts.
}

\author{
P. Jaloviar, M. Saniga, S. Kucbel
}

Katedra pestovania lesa, Lesnícka fakulta, Technická univerzita vo Zvolene, Masarykova 24, SK-960 01 Zvolen, Slovenskárepublika,E-mail:jaloviar@tuzvo.sk,kucbel@tuzvo.sk,saniga@tuzvo.sk

Abstract: Jaloviar P., Saniga M., Kucbel S. 2013: Importance of light conditions for the height growth of underplatings in Norway spruce stands in the Oravské Beskydy Mts. -Beskydy, 6 (1): 53-58

The study analyses the relationships between the components of relative irradiance and density of parent Norway spruce stand as well as the impact of light on height growth and crown architecture of beech and fir underplantings and natural regeneration of spruce. We observed three variants of regeneration: fir underplanting, beech underplanting and spruce natural regeneration. For each variant three circular research plots with the size $500 \mathrm{~m}^{2}$ were established. To determine the intensity of relative irradiance 15 hemispherical photographs in the height of $1.5 \mathrm{~m}$ were taken for each variant. The analysis confirmed a significant relationship only between indirect site factor (ISF) and basal area and partly stem number of parent stand. There is almost no influence of spruce overstorey density (within the observed range of basal area and stem number) on the values of total site factor (TSF) and its main component direct site factor(DSF). The relevant predictor for the heightincrements of underplanted saplings is ISF. Relationship between TSF and height increment is weak. Apical dominance ratio (ADR) that was used to characterize crown architecture is significantly correlated with ISF only for beech and fir. In the case of spruce, increase of light intensity in the observed range does not lead to a significant change of saplings crown architecture.

Keywords: Norway spruce, silver fir, common beech, underplantings, stand conversion, hemispherical photographs, canopy cover

\section{Introduction}

Conversion of single-species plantations of Norway spruce (Picea abies (L.) Karst.) to mixedspecies stands is one type of restoration practice currently being used. Nevertheless, Norway spruce remains commercially important tree species, but the condition for its rational cultivation is the creation of forest stands differentiated by age and tree species, with its adequate proportion. Sustainable forestry can be achieved by measures such as conversion of parts of the widespread coniferous plantations into areas with more natural broadleaved species (Löf et al. 2004), underplantings of monocultures or natural regeneration of mixed and differentiated stands. Thereby, mainly common beech (Fagus sylvatica L.) and other shade tolerant broadleaved tree species will be introduced to the stands. The conversion will primarily be achieved by removing single target diameter trees and creating small gaps (Heinrichs, Schmidt 2009).

It is widely recognized that shade tolerance is not an unchangeable attribute of a tree species (Coomes, Grubb 2000). For the very concept of shade tolerance, there is no uniquely satisfactory definition because of negative correlation between rate of growth and rate of survival in deep shade. In general, the light demands of the majority of tree species are growing with increasing age. At the same time, the more extreme is the site in terms of watter and nutrient supply, the higher are tree's demands on light. 
For the practice of silviculture this means that in the case of nutrient-poor sites the period of shading should be adequately reduced (Burschel, Huss 1997).

Therefore, the optimal regulation of density in Norway spruce overstorey represents the most important factor for the successful development of realised underplatings. Canopy closure is one of the stand attributes that can be most easily manipulated by silvicultural measures (Löf et al. 2007). Changes in canopy closure can modify the light conditions in stand interior in a very different level. The changes in light transmission are very complicated because light penetration in mature spruce stand is affected not only by canopy form, stand height, crown ratios and needle mass but also by terrain conditions such as slope, aspect etc.

Currently, the methods are available that can quantify the amount of light (PAR) under the stand canopy with reasonable accuracy. The method based on the use of hemispherical photographs (Evans, Coombe 1959, Chazdon, Field, 1987, Dohrenbusch 1994, Wagner 1994, Promis et al, 2012, Gonsamo 2010) provides reliable information about the basic parameters of the relative irradiation in stand interior. One of the outputs, the indirect site factor (ISF), is according to Ishida, Peters (1998) better predictor of shoot extension rates as direct (DSF) and total site factor (TSF), although ISF is rather minor component of radiation.

The aim of this study is to assess the impact of the relative light intensity and its components on height growth of beech and fir underplantings in the Forest District Paráč (the Oravské Beskydy Mts.). Another objective is to derive the relationships between relative light and basic stand characteristics that are used in forestry practice to describe the stand density and thus indirectly also the light conditions in stand interior.

\section{Materials and methods}

The object of the research was a 110 years old pure Norway spruce forest stand located in physiographic region of the Oravské Beskydy Mts. (northern Slovakia) in 850-900 m a.s.l. The annual amount of precipitation in the last decade is $1120 \mathrm{~mm}$ and mean temperature is $4.6^{\circ} \mathrm{C}$. The parent rock is flysch with dominance of sandstones, the soil type is gleyic cambisol.

The stand examined in this study can be described as Fagetum abietinum and Fagetum abietinopiceosum (i.e. 9110 Luzulo-Fagetum in system of Natura 2000). In the case of natural tree species composition, spruce would represent only a small portion of stand growing stock. At present, the proportion of spruce in studied stand is nearly $94 \%$, beech reaches $2.7 \%$ and fir $2.6 \%$ of the growing stock $450-470 \mathrm{~m}^{3} \cdot \mathrm{ha}^{-1}$. The stand is at the end of rotation and its regeneration is planned by $60 \%$ as artificial and $40 \%$ as natural regeneration. The tree species composition in future stand should consist of $60 \%$ spruce, $20 \%$ fir and $20 \%$ beech. Artificial regeneration is mainly done by dug-hole method or to a lesser extent by bar-slit method (beech).

Because spruce is an important and desirable commercial tree species, the goal is to preserve it in the stands but at the same time to stabilize the stands by increasing the proportion of fir and beech. In this situation, it was a good solution to use the beech and fir underplantings in groups combined with natural regeneration of spruce emerging as a consequence of successive target diameter harvesting of overstorey trees. The studied stand has been systematically underplanted since the 1990s. Height of the oldest underplantings currently reaches approximately $4 \mathrm{~m}$ while the youngest underplantings (the subject of this study) have a maximum height of $1.5 \mathrm{~m}$. Because of their height and spacing, these younger underplantings do not form a compact stand layer and the underplantings of different age are spatially separated.

We studied three stand types: pure spruce stand with natural regeneration of spruce (ps), pure spruce stand with beech underplanting (b/s) and pure spruce stand with fir underplanting (f/s). In year 2012, 9 circular research plots with the radius of $12.5 \mathrm{~m}\left(500 \mathrm{~m}^{2}\right)$ were established in the surveyed stand. Three plots were positioned to capture beech underplantings, another three plots captured fir underplantings with the condition of no browsing damage since 2007. The last 3 plots were placed in spruce stand with pure natural regeneration of spruce (ps) with the height up to $1 \mathrm{~m}$. Common for all studied plots was the spruce proportion in overstorey above $90 \%$ and uniform underplanting density in the entire area.

In each sample plot the polar coordinates of the positions for all overstorey trees were recorded. On each overstorey stem we measured following characteristics: height, crown base height, diameter at breast height (dbh) and crown width in two perpendicular directions. These data were used for the calculation of basal area and canopy closure (Tab. 1).

In each plot we randomly selected 5 sample points, where the relative light and the parameters of regeneration individuals (underplanted or from natural regeneration) were registered. 
in Norway spruce stands in the Oravské Beskydy Mts.

Tab. 1: Mean dendrometric characteristics of Norway spruce stands on the studied plots.

\begin{tabular}{|c|c|c|c|c|c|c|}
\hline $\begin{array}{c}\text { Plot with tested } \\
\text { species }\end{array}$ & $\begin{array}{c}\begin{array}{c}\text { Stem } \\
\text { number }\end{array} \\
{\left[\mathrm{ha}^{-1}\right]}\end{array}$ & $\begin{array}{l}\mathbf{d b h} \\
{[\mathrm{cm}]}\end{array}$ & $\begin{array}{c}\text { Basal area } \\
{\left[\mathrm{m}^{2} \cdot \mathrm{ha}^{-1}\right]}\end{array}$ & $\begin{array}{c}\text { Dominant } \\
\text { height } \\
{[\mathrm{m}]}\end{array}$ & $\begin{array}{c}\text { Crown } \\
\text { width } \\
{[\mathrm{m}]}\end{array}$ & $\begin{array}{c}\text { Sum of crown } \\
\text { projections } \\
{\left[\mathrm{m}^{2} . \mathrm{ha}^{-1}\right]}\end{array}$ \\
\hline Spruce (ps) & 213 & 40.3 & 34.79 & 37 & 4.8 & 4574 \\
\hline $\operatorname{Beech}(b / s)$ & 267 & 41.2 & 45.32 & 36 & 5.0 & 4087 \\
\hline $\operatorname{Fir}(\mathbf{f} / \mathbf{s})$ & 267 & 41.7 & 46.36 & 38 & 4.9 & 4957 \\
\hline
\end{tabular}

Light conditions were assessed by the use of hemispherical photographs for each point, above the tree top, taken in standard overcast conditions at the 7th August 2012. Photographs were processed with WinScanopy software (Regent Instruments, CA). We used a Mid-O-Mount 10 MP version of WinScanopy software and grey scale based pixel classification (so called global threshold). The threshold value was set automatically. Output variables that were in the following used to characterize the light environment were: direct (DSF), indirect (ISF) and total (TSF) site factors. Direct site factor (DSF) is the proportion of direct solar irradiation at a given point relative to that in the open. Indirect site factor or diffuse site factor (ISF) is the proportion of diffuse solar irradiation and total site factor (TSF) or global site factor is the proportion of global solar irradiation at a given point relative to that in the open. TSF is calculated as the sum of both the direct and diffuse site factor, weighted by their contribution to the photon flux density.

In the immediate neighbourhood of each sample point we measured for five nearest regeneration individuals (underplanted or from natural regeneration) the following parameters: tree height, height increments of the last 3 years, lateral increment of the last year and crown width in two perpendicular directions. Apical dominance ratio (ADR) was calculated as a ratio of height increment to the length of lateral shoot of the last year. Relative growth ratio (RGR) was calculated as a ratio of height increment to sapling height (Szymura 2005).

\section{Results and discussion}

The values of relative irradiance parameters in particular plots (Tab. 2) are relatively low, if we consider that the sample plots are located in commercial forest with advanced phase of regeneration. The light conditions are homogeneous within the plots, however, the plots with fir underplantings receive significantly less light. Values of openness are not correlated with site factors, but there are significant correlations between the site factors. High degree of correlation between the ISF and DSF for temperate forests with the coefficient of determination higher than 0.80 was reported by Ishida, Peters (1998). Parent, Messier (1996) consider instantaneous measurements of indirect site factor for suitable predictor of total irradiance exactly due to existing strong correlation between TSF and ISF within a given forest type.

Relationship between the parameters of relative light and basic characteristics of parent stand density (basal area, stem number) was analyzed by the method of linear correlation and regression analysis. As the type and character of the following stand generation have no influence on these relationships, all partial plots were evaluated together (Tab. 3).

Basal area is significantly correlated only with openness and ISF. We found no significant relationships in other cases and therefore relevant relationships between stem number and any parameter of relative irradiance or between basal area and DSF and TSF were not confirmed. Relationship between stand density, expressed by basal area, stem number, growing stock, canopy cover or by some more complex indicator and DSF is mainly in open stands often very weak, precisely because DSF is highly influenced by

Tab. 2: Relative irradiance in spruce stand in the height 1-1.5 m above the ground. Letters represent homogeneous groups according to Duncan's test at $\alpha=5 \%$.

\begin{tabular}{lcccc}
\hline \multicolumn{1}{c}{ Plot } & Openness & DSF & ISF & TSF \\
\hline ps & $10.65 \pm 0.17^{\mathrm{a}}$ & $0.18 \pm 0.030^{\mathrm{a}}$ & $0.21 \pm 0.004^{\mathrm{a}}$ & $0.19 \pm 0.020^{\mathrm{a}}$ \\
$\mathbf{b} / \mathbf{s}$ & $9.50 \pm 0.22^{\mathrm{b}}$ & $0.20 \pm 0.014^{\mathrm{a}}$ & $0.20 \pm 0.004^{\mathrm{a}}$ & $0.20 \pm 0.012^{\mathrm{a}}$ \\
$\mathbf{f} / \mathbf{s}$ & $10.17 \pm 0.19^{\mathrm{a}}$ & $0.13 \pm 0.009^{\mathrm{b}}$ & $0.18 \pm 0.005^{\mathrm{b}}$ & $0.14 \pm 0.009^{\mathrm{b}}$ \\
\hline
\end{tabular}


Tab. 3: Parameters of linear regressions between basic characteristics of parent stand density (basal area, stem number) and characteristics of relative irradiance $\left({ }^{*}-\alpha=5 \%,{ }^{* *}-\alpha=1 \%,{ }^{* * *}-\alpha=0.1 \%,\right)$.

\begin{tabular}{lcclll}
\hline $\begin{array}{c}\text { Independent } \\
\text { variable }\end{array}$ & $\begin{array}{c}\text { Regression } \\
\text { parameter }\end{array}$ & Openness & DSF & ISF & TSF \\
\hline \multirow{3}{*}{ Basal area } & $\mathrm{a}$ & $13.3^{* * *}$ & 0.15 & $0.25^{* * *}$ & 0.16 \\
& $\mathrm{~b}$ & $-0.62^{*}$ & 0.0030 & $-0.0014^{*}$ & 0.00012 \\
& $\mathrm{r}^{2}$ & $0.51^{*}$ & 0.14 & $0.55^{*}$ & 0.14 \\
Stem number & $\mathrm{a}$ & $13.1^{* * *}$ & 0.06 & $0.24^{* * *}$ & 0.08 \\
& $\mathrm{~b}$ & -0.009 & 0.0004 & 0.0001 & 0.0003 \\
& $\mathrm{r}^{2}$ & 0.44 & 0.12 & 0.36 & 0.10 \\
\hline
\end{tabular}

the position of canopy gaps to the point of measurement. Moreover, mentioned variables do not take into account the mutual positions of tree crowns or the do it only minimally. The use of dendrometric indicators of stand density is more difficult and less accurate for shade-bearing tree species with the ability to rapid expansion of their lateral shoots into emerging canopy gaps (Dohrenbusch 1989). However, in the case of light-demanding tree species with higher level of transmitted light a stronger correlation between stand density and direct radiation can be expected. The cause of the weak correlation between TSF and stand density is the fact that regarding PPFD the direct light has a significantly larger share on the total irradiance as indirect light (Chazdon, Field 1987).

The best growing tree species of subsequent stand generation is beech. At the same age it reaches more than twofold height compared to spruce. Similarly, regarding the height increment the growth of beech is most intense. Though spruce saplings originate from natural regeneration, the height growth of spruce is the significantly weakest (Tab. 4). At the same time, the research plots with spruce natural regeneration have on average the lowest overstorey density regarding stem number and basal area and a comparable sum of crown projections. Comparable values of RGR (5-10\%) for spruce and fir natural regeneration in selection forests were reported by Diaci, Firm (2011), Duc (1991), or Klopcic, Boncina (2010).

For conifers (spruce, fir), the values of apical dominance ratio (ADR) are below 1, i.e. they form umbrella shape crowns. Crown architecture of beech saplings represents a transition between umbrella shape and conical crown. Despite the prevailing umbrella shape crowns, fir has the highest relative growth ratio.

Response of subsequent stand generation of most our tree species to increasing light intensity is positive. Increased irradiation leads to more intensive growth of natural regeneration or trees located in the lower stand layers (Vencurik 2004, 2007). According to Vencurik (2006) height increment of spruce and fir in selection forests depends only on the light conditions and not on the side competition of neighbouring trees.

Relationships between particular parameters of relative irradiance and growth parameters of underplantings or natural regeneration of spruce are similar to those of relative irradiance parameters and dendrometric characteristics of overstorey (Fig. 1). ISF is more closely correlated with all studied variables in the case of underplanted tree species (beech and fir). Height increment of beech in 2012 had the strongest relationship to ISF among all examined variables ( $\mathrm{r}$ $=0.632 *$ ). Relative growth ratio is not correlated to any parameter of relative light (ISF, DSF or TSF) in the case of both conifers, however the

Tab. 4: Mean values ( \pm SE) of basic biometric parameters of underplantings and natural regeneration. Letters represent homogeneous groups according to Duncan's test at $\alpha=5 \%$.

\begin{tabular}{lcccccc}
\hline $\begin{array}{c}\text { Tree } \\
\text { species }\end{array}$ & $\begin{array}{c}\text { Height } \\
{[\mathbf{c m}]}\end{array}$ & $\begin{array}{c}\mathbf{i}_{\mathrm{h} 2012} \\
{[\mathbf{c m}]}\end{array}$ & $\begin{array}{c}\mathbf{i}_{\text {h2011 }} \\
{[\mathbf{c m}]}\end{array}$ & $\begin{array}{c}\mathbf{i}_{\text {h2010 }} \\
{[\mathbf{c m}]}\end{array}$ & $\mathbf{R G R}_{\mathbf{2 0 1 2}}$ & ADR $_{2012}$ \\
\hline Spruce & $70.1 \pm 3.2^{\mathrm{a}}$ & $5.8 \pm 0.3^{\mathrm{a}}$ & $5.6 \pm 0.3^{\mathrm{a}}$ & $5.4 \pm 0.3^{\mathrm{a}}$ & $0.09 \pm 0.004^{\mathrm{a}}$ & $0.79 \pm 0.03^{\mathrm{a}}$ \\
Beech & $152.1 \pm 6.4^{\mathrm{b}}$ & $17.8 \pm 1.1^{\mathrm{b}}$ & $14.0 \pm 0.9^{\mathrm{b}}$ & $12.4 \pm 0.8^{\mathrm{b}}$ & $0.12 \pm 0.007^{\mathrm{b}}$ & $1.01 \pm 0.04^{\mathrm{b}}$ \\
Fir & $99.2 \pm 4.4^{\mathrm{c}}$ & $13.2 \pm 0.6^{\mathrm{c}}$ & $10.3 \pm 0.5^{\mathrm{c}}$ & $9.1 \pm 0.5^{\mathrm{c}}$ & $0.13 \pm 0.004^{\mathrm{b}}$ & $0.86 \pm 0.03^{\mathrm{a}}$ \\
\hline
\end{tabular}




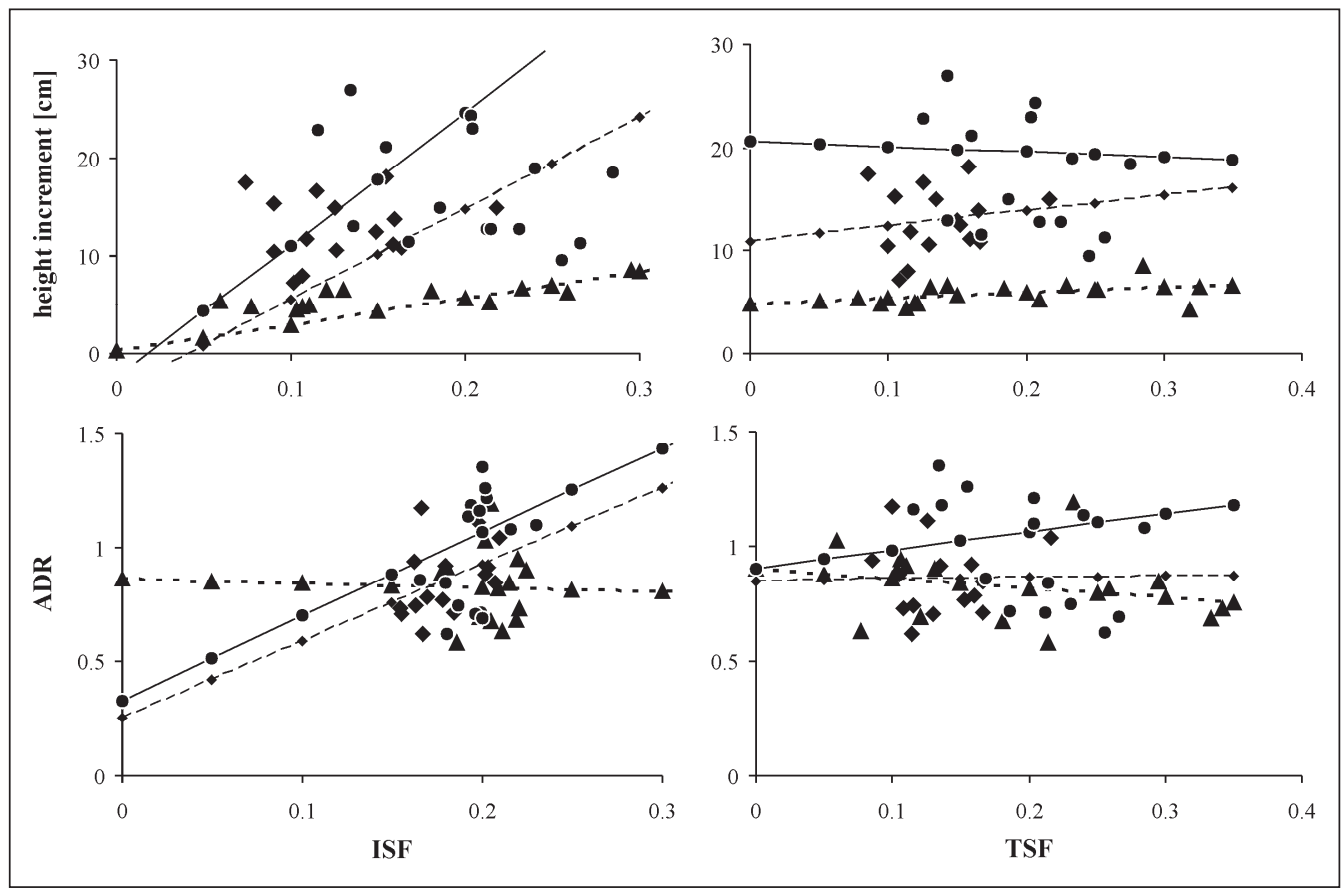

Fig. 1: Relationships between parameters of relative irradiance (ISF and TSF) and height increment 2012 and ADR for particular tree species (beech - circles and solid line, fir - squares and dashed line with square markers, spruce - triangles and dotted line with triangle markers).

analysis confirmed a positive relationship between RGR and diffuse light for beech.

Underplanted tree species show higher correlations than natural regeneration of spruce at their similar height. At the same time, the plots with natural regeneration of spruce are comparable to those of beech regarding the light conditions (Tab. 2). Despite significantly lower light intensity, fir reaches the increments comparable to beech, and also their relationship to the parameters of relative light is significant.

Crown architecture (umbrella shape) of spruce do not change significantly with increasing light. On the contrary, reaction of beech and fir is significant and with increasing light intensity their crowns change from umbrella shape to conical crown.

\section{Conclusions}

In conclusion, the intensity of light under the parent stand is influenced by crown canopy structure of overstorey. However, particular components of irradiation are impacted to various extent and it was confirmed that density of parent stand expressed by its basal area or by sum of crown projections impacts especially the quantity of diffuse component. Direct light under the canopy is strongly modified also by other variables and therefore its prediction based only on production characteristics of overstorey is extremely inaccurate or even impossible.

Basal area can be used as the predictor of diffuse light that is moreover the most strongly correlated with height increment and apical dominance ratio of subsequent stand generation. Besides the strength of correlation, in the case of underplanted tree species is important also the high influence of diffuse light on the height increment.

While the given light conditions are sufficient for the growth of underplantings, for the spruce natural regeneration is this light intensity insufficient. On the other hand, these light conditions make possible to reach the goal that is the reintroduction of fir and beech into monocultures of spruce, moreover at the maximum utilization of value production of parent stand. The more intensive decreasing of overstorey density would cause the higher light intensity in stand interior and thus very likely rapid growth of spontaneous and abundant natural regeneration of spruce. 


\section{Acknowledgement}

This publication is the result of the project implementation: Extension of the Centre of Excellence "Adaptive Forest Ecosystems“, ITMS: 26220120049 , supported by the Research \& Development Operational Programme funded by the ERDF.

\section{References}

Burschel, P., Huss, J., 1997: Grundriß des Waldbaus. Parey Buchverlag, Berlin, 487 pp.

Coomes, D. A. 2000: Impact of root competition in forests and woodlands: a theoretical framework and review experiments. Ecological Monographs, 171-207.

DiACI, J., FiRM, D. 2011: Long-term dynamics of a mixed conifer stand in slovenia managed with a farmer selection system. Forest Ecology and Management, 262: 931-939.

Duc, P. 1991: Untersuchungen zur Dynamik des Nachwuchses in Emmentaler Plenterflächen. Schweizerische Zeitschrift für Forstwesen, 142 (4): 299-319.

Dohrenbusch, A. 1989: Die Anwendung fotographischer Verfahren zur Erfassung des Kronenschlußgrades. Forstarchiv, 60: 151-155.

Dohrenbusch, A., 1994: Überlegungen zur Optimierung der Strahlungmessungen im Wald. Allgemeine Forst- und Jagdzeitung, 166: 109-114.

Evans, G.C., Coombe, D.E. 1959: Hemisperical and Woodland Canopy Photography and the Light Climate. Journal of Ecology, 47 (1): 103-113.

Gonsamo, A., Walter, J-M. N., Pellikka, P. 2010: Samplong gap fraction and size for estimating leaf area and clumping indices from hemispherical photographs. Canadian Journal of Forest Research, 40 (8):1588-1603.

Heinrichs, S., Schmidt, W. 2009: Short-term effects of selection and clear cutting on the shrub and herb layer vegetation during the conversion of even-aged Norway spruce stands into mixed stands. Forest Ecology and Management, 258 (5): 667-678.

IsHidA, M., Peters, R. 1998: Effects of potential PAR on shoots extension in juveniles af the main tree species in Japanese temperate forest. Ecological Research, 13: 171-182.

Chazdon, R.L., Field, C.B. 1987: Photographic estimation of photosynteticaly active radiation,: evaluation of a computerized technique. Oecologia, 73: 525-532.
Klopcic, M., Boncina, A. 2010: Patterns of tree growth in a single tree selection silver firEuropean beech forest. European Journal of Forest Research, 15:21-30.

Löf, M., Isacson, G., Rydberg, D., Welander, T.N. 2004: Herbivory by the pine weevil (Hylobius abietis L.) and short-snouted weevils (Strophosoma melanogrammum Forst. and Otiorhynchus scaber L.) during the conversion of a wind-thrown Norway spruce forest into a mixed-species plantation Forest Ecology and Management, 192 (2-3): 281-290.

Löf, M., Karlsson, M., Sonesson, K., Welander, T.N., Collet, C. 2007: Growth and mortality in underplanted tree seedlings in response to variations in canopy closure of Norway spruce stands Forestry, 80 (4): 371-384.

Parent, S., Mesier, C. 1996: A simple and efficient method to estimete microsite light availability under a forest canopy. Canadian Journal of Forest Research, 26:151-154.

Promis, A., Caldentey, J., Cruz, G. 2012: Evaluating the usefullness of hemispherical photographs as a means to estimate photosyntetic photon flux density durind a growing season in the understorey of Nothofagus pumilio forests. Plant Biosystems, 146 (1):237-243.

Szymura, T.H. 2005: Silver fir sapling bank in seminatural stand: Individuals architectura and vitality. Forest Ecology and Management, 212: 101-108.

Vencurik, J. 2004: Dynamika výškových presunov smreka (Picea abies (L.) Karst) spodnej vrstvy výberkového lesa v oblasti Oravských Beskýd. Beskydy, 17: 95-102.

VencuriK, J. 2006: Dynamika výškového rastu stromov v dolnej vrstve výberkového lesa v orografickom celku Volovské vrchy. Acta Facultatis Forestalis, 48: 171-181.

VENCURIK, J. 2007: Výškový rast smreka a jedle v dolnej vrstve výberkového lesa. Acta Facultatis Forestalis, 49: 173-184.

WAGNER, S., 1994: Strahlschätzung in Wäldern durch hemisphärische Fotos, Methode und Anwendung. Dissertation zur Erlangung des Doktorgrades, Göttingen, 166 pp. 